Int. J. Electrochem. Sci., 14 (2019) 7076 - 7087

\title{
Effect of Temperature on Physical and Electrochemical Properties of the Monolithic Carbon-Based Bamboo Leaf to Enhanced Surface Area and Specific Capacitance of the Supercapacitor
}

\author{
B. Armynah ${ }^{1,2}$, E. Taer ${ }^{3}$, Z. Djafar ${ }^{1}$, Wahyu H. Piarah', D. Tahir ${ }^{2, *}$, \\ ${ }^{1}$ Departement of Mechanical Engineering, Hasanuddin University, Bantumarannu Goa 92171 \\ Indonesia \\ ${ }^{2}$ Departement of Physics, Hasanuddin University, Tamalanrea Makassar 90245 Indonesia \\ ${ }^{3}$ Department of Physics, University of Riau, 28293 Simpang Baru, Riau, Indonesia \\ *E-mail: dtahir@fmipa.unhas.ac.id
}

doi: $10.20964 / 2019.08 .59$

Received: 2 April 2019 / Accepted: 25 May 2019 / Published: 30 June 2019

\begin{abstract}
Several analysis have been conducted on the physical and electrochemical properties of monolithic carbon-based bamboo leaf for supercapacitor application. Therefore, the main focus of this study was to analyze the relationship between pore diameter, surface area, and specific capacitance. The variations of pore diameter were found using the activation temperature in the range of $750{ }^{\circ} \mathrm{C}, 800{ }^{\circ} \mathrm{C}$, $850{ }^{\circ} \mathrm{C}$, and $900{ }^{\circ} \mathrm{C}$. The carbon electrode was prepared in the monolithic form to ensure there is no disturbance with the natural pore of the electrode in the presence of adhesives. The physical properties analyzed include (i) thermal properties, (ii) surface morphology, (iii) elemental content (iv) crystallinity properties and (v) $\mathrm{N}_{2}$ gas adsorption-desorption isotherm. Furthermore, the specific capacitance was determined through the use of Cyclic Voltammetry (CV) as the electrochemical characteristic. It was discovered that the specific capacitance varies with average pore diameter such that a higher specific capacitance was found with pore diameters smaller than $1.5 \mathrm{~nm}$ and the value increased with the size. This research was supported by analysis of surface morphology, elemental content, thermal resistance, and degree of crystallinity.
\end{abstract}

Keywords: bamboo leaf; activated carbon; biomass

\section{$\underline{\text { FULL TEXT }}$}

(C) 2019 The Authors. Published by ESG (www.electrochemsci.org). This article is an open access article distributed under the terms and conditions of the Creative Commons Attribution license (http://creativecommons.org/licenses/by/4.0/). 